\title{
Acute thrombosis on a carotid web associated with an ipsilateral embolic stroke
}

Mohammed Wadhah AI-Dulaimi, MD, Mohamed Ridha, MD, Juan E. Small, MD, Matthew Tilem, MD, Barbara Voetsch, MD, PhD, and Johanna Helenius, MD, PhD

Neurology ${ }^{\circledR}$ 2020;95:931-932. doi:10.1212/WNL.0000000000010972

\author{
Correspondence \\ Dr. Al-Dulaimi \\ maldulaimi@ \\ tuftsmedicalcenter.org
}
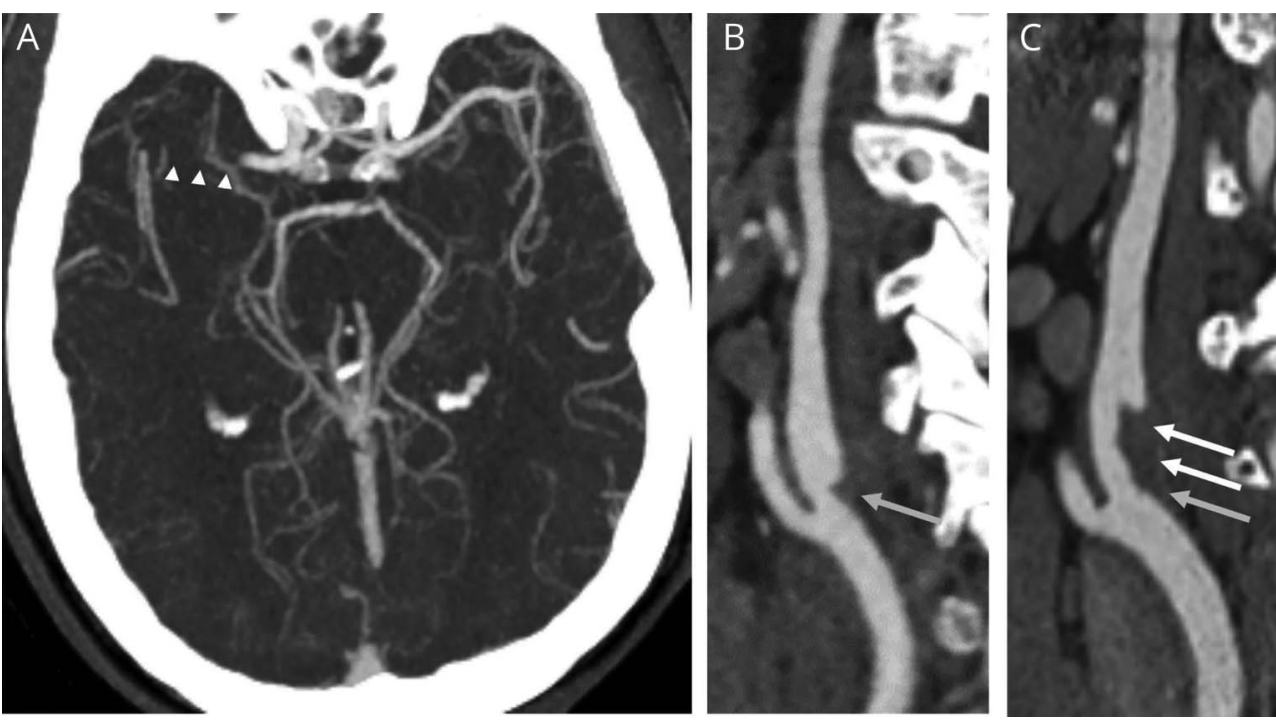

(A) CTA at presentation demonstrates a right M1 occlusion (arrowheads). (B) Sagittal CTA at presentation demonstrates a shelf-like filling defect along the posterior internal carotid artery bulb consistent with a carotid web (gray arrow). (C) A CTA performed 25 hours later shows new thrombus along the web (white arrows).

A 56-year-old man without cardiovascular risk factors presented with an acute right middle cerebral artery stroke (figure, A) treated by IV tissue plasminogen activator and endovascular thrombectomy. CT angiogram (CTA) showed a triangular filling defect along the posteromedial margin of the proximal right internal carotid artery (ICA) consistent with a carotid web (CaW), without atherosclerosis (figure, B). Follow-up CTA within 2 days revealed evolving in situ thrombus overlying the $\mathrm{CaW}$ (figure, $\mathrm{C}$ ), after which anticoagulation was started. $\mathrm{A} \mathrm{CaW}$ is a shelf-like linear filling defect of the ICA bulb thought to represent an intimal variant of fibromuscular dysplasia. ${ }^{1}$ Hypothetically, blood stasis along CaW downstream surface may cause thrombus formation and thromboembolic strokes. ${ }^{2}$

\section{Study funding}

No targeted funding reported.

\section{Disclosure}

The authors report no disclosures. Go to Neurology.org/ $\mathrm{N}$ for full disclosures. 
Appendix Authors

\begin{tabular}{lll}
\hline Name & Location & Contribution \\
\hline $\begin{array}{l}\text { Mohammed Al- } \\
\text { Dulaimi, MD }\end{array}$ & $\begin{array}{l}\text { Tufts Medical Center, } \\
\text { Boston, MA }\end{array}$ & $\begin{array}{l}\text { Drafted the } \\
\text { manuscript }\end{array}$ \\
\hline $\begin{array}{l}\text { Mohamed } \\
\text { Ridha, MD }\end{array}$ & $\begin{array}{l}\text { Tufts Medical Center, } \\
\text { Boston, MA }\end{array}$ & $\begin{array}{l}\text { Drafted the } \\
\text { manuscript }\end{array}$ \\
\hline $\begin{array}{l}\text { Juan E. Small, } \\
\text { MD }\end{array}$ & Lahey Hospital and Medical & $\begin{array}{l}\text { Acquisition and } \\
\text { analysis of images }\end{array}$ \\
\hline $\begin{array}{l}\text { Matthew } \\
\text { Tilem, MD }\end{array}$ & Lenter, Burlington, MA & $\begin{array}{l}\text { Provided clinical } \\
\text { Center, Burlington, MA }\end{array}$ \\
\hline $\begin{array}{l}\text { Barbara } \\
\text { Voetsch, MD, } \\
\text { PhD }\end{array}$ & Lahey Hospital and Medical \\
\hline
\end{tabular}

Appendix (continued)

\begin{tabular}{lll}
\hline Name & Location & Contribution \\
\hline $\begin{array}{l}\text { Johanna } \\
\text { Helenius, MD, } \\
\text { PhD }\end{array}$ & $\begin{array}{l}\text { Lahey Hospital and Medical } \\
\text { Center, Burlington, MA }\end{array}$ & $\begin{array}{l}\text { Study concept, design, } \\
\text { and coordination }\end{array}$ \\
\hline
\end{tabular}

\section{References}

1. Choi PM, Menon BK, Demchuk AM. Carotid web and stroke. Eur J Neurol 2014;21 e53.

2. Choi PM, Singh D, Trivedi A, et al. Carotid webs and recurrent ischemic strokes in the era of CT angiography. AJNR Am J Neuroradiol 2015;36:2134-2139.

\section{COVID-19 and Neurologic Disease: Call for Papers!}

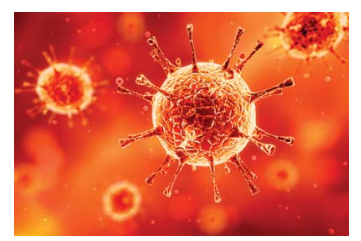

The editors of Neurology are interested in papers that address the neurological aspects of COVID-19 infection and challenges to the management of patients with chronic neurological conditions who have, or are at risk for, the infection. Relevant papers that pass initial internal review will undergo expedited peer review and online publication. We will consider papers posted in preprint servers.

Submit observational studies and clinical trials as Articles and case series and case reports under the Clinical/Scientific Notes category to https://submit.neurology.org/ today!

\section{Sign Up for the AAN's Axon Registry}

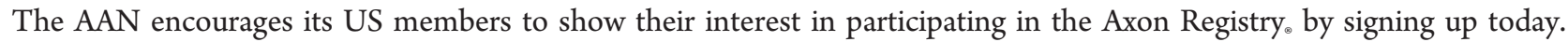

Use the Axon Registry to:

- Simplify reporting requirements under MACRA's Quality Payment Program and avoid penalties while reducing your administrative burden

- Meet your MOC Part IV requirements and waive up to eight credits of Part II Self-Assessment

- Choose from 22 AAN neurology-specific quality measures that fit your practice

- Use data to understand your practice and identify where improvements can be made to patient care

- Manage your patients at a population level; look at a specific group of patients based on conditions, risk factors, demographics or outcome

- Demonstrate your value to payers when negotiating reimbursement

- Enjoy multi-year, fee-free access when you sign the agreements and integrate your EHR with the registry

Learn more at AAN.com/view/Axon and send your questions to registry@aan.com. 


\section{Neurology}

\section{Acute thrombosis on a carotid web associated with an ipsilateral embolic stroke}

Mohammed Wadhah Al-Dulaimi, Mohamed Ridha, Juan E. Small, et al.

Neurology 2020;95;931-932 Published Online before print October 1, 2020

DOI 10.1212/WNL.0000000000010972

This information is current as of October 1, 2020

\section{Updated Information \&} Services

\section{References}

Subspecialty Collections

Permissions \& Licensing

Reprints including high resolution figures, can be found at: http://n.neurology.org/content/95/20/931.full

This article cites 2 articles, 1 of which you can access for free at: http://n.neurology.org/content/95/20/931.full\#ref-list-1

This article, along with others on similar topics, appears in the following collection(s):

CT

http://n.neurology.org/cgi/collection/ct

Embolism

http://n.neurology.org/cgi/collection/embolism

Other cerebrovascular disease/ Stroke

http://n.neurology.org/cgi/collection/other_cerebrovascular_disease_st roke

Information about reproducing this article in parts (figures,tables) or in its entirety can be found online at:

http://www.neurology.org/about/about_the_journal\#permissions

Information about ordering reprints can be found online:

http://n.neurology.org/subscribers/advertise

Neurology ${ }^{\circledR}$ is the official journal of the American Academy of Neurology. Published continuously since 1951 , it is now a weekly with 48 issues per year. Copyright (C) 2020 American Academy of Neurology. All rights reserved. Print ISSN: 0028-3878. Online ISSN: 1526-632X.

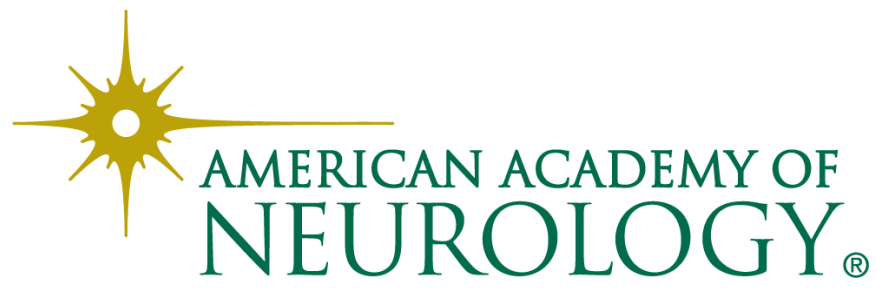

